\title{
Teaching Speaking Skills: Practices and Techniques in Rural Schools
}

\author{
Pramela Krish $^{1 *} \quad$ Siti Zubaidah Mustafa ${ }^{2} \quad$ Farhan Ahlaamie Pakrudin ${ }^{3}$ \\ 1. Faculty of Social Sciences and Humanities, Universiti Kebangsaan Malaysia \\ 2 Sekolah Kebangsaan Pulau Perhentian, Kuala Besut, Terengganu, Malaysia \\ 3. Maahad Sains Tok Guru, Pengkapan Chepa, Kelantan, Malaysia
}

\begin{abstract}
The issue of speaking proficiency among students has always been a concern. Studies have shared findings to say students lack proficiency that contributes to poor speaking skills. This study aims to explore and investigate the teaching practices and techniques of speaking skills among secondary school teachers in selected rural schools. This qualitative study was carried out with ten English teachers selected from several schools in a district in Kelantan. Data were collected and analysed based on classroom observations and interviews. The curriculum specifications and lesson plans were also studied. The findings showed that teachers still practised the traditional teacher-centred approach. The teachers were also highly dependable on textbooks as their teaching material. However, only a few teachers were found to have moved into innovative ways of teaching speaking skills. The investigation also found a variety of challenges faced by teachers in the teaching of speaking skills. On the whole, this paper suggests that teachers should be given ample opportunities to receive the necessary training to teach speaking skills effectively.
\end{abstract}

Keywords: teaching practices; communicative language teaching; speaking skills; second language acquisition; communicative competence

DOI: $10.7176 / \mathrm{JEP} / 10-29-15$

Publication date:October $31^{\text {st }} 2019$

\section{Introduction}

English as the global language for communication has become an absolute necessity. In many parts of the globe, English education is playing a significant role especially in non-English speaking countries around the world. Many countries emphasise on the English language in their education system; this is evident in the Asian countries where the English language has become the main international language (Rose \& McKinley 2018). In Malaysia, the national language is Bahasa Malaysia (BM) or the Malay language while English plays a significant role as the second language (L2) throughout the country. Therefore, to be able to communicate effectively, the Ministry of Education (MOE) has made it compulsory for everyone to learn English at school starting from preschool to tertiary level. Teaching speaking skills is vital to improving students' communicative competence.

Malaysia recognises the importance of English as an international language of communication (Malaysia Education Blueprint 2015-2025 (Higher Education) 2016). It is for this reason that the government continues to take necessary actions and measures to ensure that the language is taught as a strong second language (Jeyaraj \& Harland, 2019). The curriculum has also been reformed in terms of policies and syllabus at national level which requires the implementations of Communicative Language Teaching (CLT) in English language education (Mohd Zulhilmi \& Radzuwan 2019).

Malaysian students have limited communicative skills even after eleven years of studying in primary and secondary schools (Tong \& Ahmad 2018). Even though the English language is the medium of instruction at the university level, many students still struggle to communicate in English for academic purpose (Jeyaraj \& Harland 2019). There is an increasing demand to speak in English at the local colleges and universities involving academic activities today. Both employers and also students come to an agreement that English plays a vital role in employability (Siti Zaidah Zainuddin, Pillai, Dumanig, \& Phillip 2019). Issues related to Malaysian students' inability to function well in the English language have long been highlighted by scholars (Lim, Melor Md Yunus, \& Mohamed Amin Embi 2017; Chin, Lim, Mok, Saw \& Tey 2017; June \& Zanariah Pilus 2019).

Studies have shown that communication skill is positioned as one of the topmost required critical skills in the job market (McMurray, Dutton, McQuaid, \& Richard, 2016; Moore \& Morton 2017). Besides, studies in the local context also confirm that communication skill is one of the major factors influencing graduate employability in Malaysia. Moreover, poor command of English is also identified as the prominent problem pointed out by the employers (Pramela, Khamisah, Subahan and Zanaton, 2014; Siti Zaidah Zainuddin, Pillai, Dumanig, \& Phillip 2019). Thus the students must master the language starting from the school level. The curriculum for teaching speaking skills should include the efforts to expose the learners to authentic and practical settings for speaking English in addition to encouraging active learning during the lessons (Husna Yahya, Abu Bakar Razali, \& Roselan Baki 2018).

More recently, it is highlighted that the teaching of L2 itself could also contribute towards accumulating more 
problems as many teachers were found to be unfit to teach language. The English teachers' teaching methods and lack of proficiency in the language, the decline in the English Language proficiency among the students (Hazlina Aziz 2016) becomes another crucial issue. This issue that relates closely to the teachers' level of English language proficiency has caught the attention of the MOE. It is stated in the Malaysia Education Blueprint 2013-2015 (Preschool to Post-Secondary Education) that almost 30\% of current English teachers were not originally trained to teach English subject while approximately 3,600 teachers were trained to teach English but are teaching other subjects as well (Chin, Lim, Mok, Saw, \& Tey, 2017). The teacher's role is an important factor in English as a second language (ESL) classroom. A successful speaking skill lesson should offer diverse ways of teaching and learning. The teachers need to accept the responsibility to encourage discussion as a significant part of the curriculum. Thus, teachers need to initiate lessons that build up the students' speaking skills.

In addressing this issue, the government had considered various incentives such as sending English teachers to courses and exchange programmes overseas to enhance their proficiency level in the language. Nevertheless, all of the strategies planned by the government would be wasted if the willingness of teachers to make changes to transform education in the country is still at the minimum level (June \& Zanariah Pilus 2019). Although English Language Teaching (ELT) practices in Malaysian schools have been given much emphasis by the government, more needs to be done. The problems that rooted from the teachers must be addressed first. The declining standard of English in this country is stemmed from poor implementation of teaching the language (Ashairi Suliman, Mohamed Yusoff Mohd Nor, \& Melor Md Yunus 2018). One example given by them is that the teaching is not fully carried out in English. The culture of learning through rote memorization and being quiet in the classroom has been stamped into each student from the moment they start school. Hence changing the atmosphere in the English Language classrooms to promote effective lessons for speaking skills is so important.

\section{The Study}

In Kelantan, the dominant language used by its people is the Kelantanese dialect. The Kelantanese dialect is even used in the formal classroom setting. Over time, this has resulted in ineffective teaching of English that subsequently affects the standard of English language among students (Sakinah Nik Muhammad Naziman \& Sharifah Raihan Syed Jaafar 2018). An issue that motivates this study is the possible effects of Communicative Language Teaching (CLT) approach on students. Ideally, this teaching approach should provide opportunities for students to interact meaningfully. Most teachers acknowledge the importance of adopting the CLT approach in their classrooms to develop the students' communicative competence in the English language. CLT has gained widespread acceptance in the world of language study. CLT can succeed, as long as teachers do not completely reject the need for the structure provided by grammar. Teachers must strive for moderation and should not neglect the merits of other methods. CLT, in the hands of a balanced teacher, can bring new life and joy to the classroom. Its vitality makes it an important contributor to language learning approaches. However, some teachers are reluctant to genuinely practise it (June \& Zanariah Pilus 2019). They still employ traditional methods or conventional teaching practices which focus more on a teacher-centred approach. The teaching processes adopt a one-way communication that is proven failure when it comes to getting the students to become fully engaged during teaching and learning sessions.

This kind of teaching practices are unable to exploit or explore students' true potentials (Husna Yahya, Abu Bakar Razali, \& Roselan Baki 2018). Teachers play a vital role in applying a set of suitable teaching practices which aim at helping the students to improve their communicative competence. Also, teachers' philosophies and practices are among the fundamental aspects in the classroom as these two elements have a direct influence on the teaching and learning process. The teaching practices used by teachers in teaching speaking skills largely determine the students' communicative competence (Jeyaraj \& Harland 2019). Thus, this paper reports on a study to investigate teaching practices of speaking skills among secondary school teachers in a district in Kelantan.

\section{Methodology}

This study is designed within a qualitative approach and it enables the researchers to uncover the multiple realities of a social setting. The research requires a specific inquiry into the teaching practices of ESL teachers. The observations serve to illustrate the actual teaching practices which ultimately define the teachers' understanding of their tasks. After several classroom observations, in-depth interviews were conducted to investigate the teaching practices in teaching speaking skills. Interviewing the teachers was essential to obtain relevant evidence which helped the researcher to describe the phenomenon of the study accurately. The sample comprising ten teachers from a district in Kelantan were selected to participate in this study. An estimated ten hours of the speaking lessons were observed and documented. A checklist by Curtain and Dahlberg (2014) were adapted and used to document the classroom activities. The constructs in the Checklist were also used to design the interview protocol for the teachers. The findings were reported according to the constructs in the checklist. To further support the data, documents like the Curriculum Specification and the lessons plans prepared by the respective teachers were randomly used for triangulation purposes. 


\section{Findings and Discussion}

The findings of the research focused on important elements to conceptualise and comprehend the fundamental issues found in response to the objectives of the research: to investigate the teaching practices and techniques for speaking skills employed by teachers and the challenges faced by them. The findings showed that most teachers agree to follow the CLT approach but they preferred a more traditional approach using non-authentic materials and employed non-communicative activities in the teaching of speaking skills in the classroom.

\section{1 Instructional Content and Presentation}

As for the instructional content and presentation, most of the teachers utilized three approaches in delivering the content and giving instructions. The teachers kept repeating and simplifying the language with Bahasa Melayu (L1). These techniques were actively used during the teaching and learning process. All teachers also employed the repetition approach to delivering the input or content to the students. The following excerpts from the interview confirm this.

\section{T3:}

T5:

"Sometimes, I repeat but I put it in other words which are simpler and easier."

"Yes, actually I was commented by one of the officers for giving too much instruction, for repeating. ... I give repetitive instructions."

T3: "I try to give some examples, simplify everything so that they could get what I mean."

T4: "Yes. I try to make my language easy for them. I choose the easy words ..."

T5: "When it is obvious that they cannot understand, somehow or rather I use simple English ..."

The teachers simplified the language because their students were unable to process what they were saying. The observations showed that all of the teachers used both L2 and L1 when conducting their speaking skills lessons. Nine out of ten teachers delivered the content and presentation in L2 more than L1. However, they tend to codeswitch from L2 to L1 whenever necessary and depending on situations. One of the reasons for using L1 in the teaching of speaking skills was to ensure that their students responded correctly to what has been taught. T3 explained that lessons which are fully conducted in L2 caused problems such as not receiving any response from students.

According to T3,

"It is because when I use English, they did not give any response that I expected. That's why I have to use the mother tongue so that, the activities could be done smoothly."

Below are more excerpts to explain the situation.

T5: "Yes, I use English but for my weak class, sometimes I do admit I use BM."

T7: $\quad$ "Yes, sometimes I have to use Malay language or translate. Sometimes, even Bahasa, they don't understand. So I need to explain in Kelantanese dialect."

T9: $\quad$ "I tried to simplify the instructions but when there is no hope, especially for the weak ones, I just straight away go to BM."

Usually, teachers use L1 to make their students understand the instructions. T1 shared that his lessons were mostly conducted in L1 than L2. He justified his action by arguing that his students normally have problems to perform any given tasks as they do not understand what is said. According to T1,

".... if I use English, maybe 5- 10 per cent of the students, will understand. The others would be off the task because they don't know what I'm talking about."

\subsection{Language Practice}

Language practice should be student-centred where the teacher plays the role of a facilitator to increase studentto-student interaction. In terms of language practice, it was very clear that all ten teachers code-switched between L2 and L1 when they interacted with the students. They used L2 in giving instructions, prompting questions, and providing feedback to the students. T5 stated that she needed to alternate the use of L1 for her weak students.

The findings also showed that almost all teachers allowed their students to make mistakes when communicating. The responses were given by T1, T3, T5, and T7 showed that they accepted students' mistakes or errors as part of the learning process.

T1: "I welcome their answers because by making mistakes, they know their mistakes and they become more confident ..."

T3: $\quad$ "Yes, I allow them to make mistakes and I do not correct them. I just want them to use the language."

T5: "Yes, I allow them to make mistakes because if I tick them one by one, they will be shy to use or speak the language."

T7: $\quad$ "Yes, it's okay for me if they made mistakes because we are teaching speaking. ... It doesn't matter if they make mistakes or not." 


\subsection{Teacher and Learner Roles}

Based on the observations, there were two primary roles carried out by the teachers in their respective classrooms. Eight teachers were found to have carried their roles as instructors. T4 and T5 facilitated the classroom interactions during speaking skills lesson. Only two teachers invited the students to give feedback and evaluate other groups' performances. There was a concrete reason for the other teachers to ignore this technique. T1 argued that students' language proficiency was generally low hence there was a barrier for them in giving feedback and evaluating other students' works. T1 said that,

"But, as I said just now, just around 5 to 10 per cent of the classroom which is what 2 or 3 students in a classroom of 23 students can understand proper English... is not that they can speak properly. So, it's kind of hard just to assign like three students to help 20 other students."

Teachers should be responsible to access their students' learning progress. Through evaluations, teachers ensure students master the skills before moving on to the next set of skills. The Curriculum Specifications for English Language (Huraian Sukatan Pelajaran Bahasa Inggeris ) (Kementerian Pendidikan Malaysia 2003) also highlights the importance of classroom evaluation. It is an essential part of the teaching and learning process. Teachers should ensure that students receive continuous feedback to keep their learning in progress. Thus, after each lesson, teachers are required to assess their students through suitable questioning techniques or other tasks so that they could pace their lessons following the students' progress.

T4 and T5 accepted their students' feedback positively as they were not being judged by the teachers. They were able to accept peer comments more than their teachers' comments. In general, peer feedback and evaluations towards other students' work are significant in the CLT approach as it aims at keeping teachers to talk at their minimum. The teachers allowed their students to correct their friends' mistakes as well as provide comments to develop students' speaking skills. Hence, the teachers must come out of their roles as instructors and try being facilitators whenever possible.

\subsection{Teaching Materials}

It was evident that six out of ten teachers relied on textbook activities when teaching speaking skills. T2, T3, T6, $\mathrm{T} 7, \mathrm{~T} 8$, and T10 relied on the textbook during the teaching of speaking skills. The main reason was that they had a time constraint to prepare other activities. T4 responded:

T4: "Sometimes, we just focus on the textbook. If we have more time maybe we can create other activities that we can add to make the lessons interesting."

Another reason shared by T4 was that textbooks were readily available and that students would normally bring textbooks to school. However, four teachers used authentic materials in teaching their speaking lessons. This kind of learning materials was used for a specified context to achieve desired learning outcomes. The teachers agreed that authentic materials supported and facilitated the students to speak better during the lesson.

T5: "Yes, it helps. Like today, the students were very good because they brought products. For example, they brought a bottle of cooking oil and other products ... to have something visual to describe."

Some of the teachers realized that they should present information through various forms such as posters or visual images like a video as well as demonstrations to make English language input as comprehensible as possible. T4, T5, and T7 shared the same response to the impact on students when they use authentic materials in the classroom. They pointed out that students were very excited and enjoyed the lessons when they used authentic material in the classroom. This situation gave a positive impact on teaching speaking skills as the students showed interest in the lessons. Showing interest is important to develop and improve their L2 speaking skills.

T4: "They look very excited. They want to know what we are going to show them."

T7: $\quad$ "They look very excited and they seem like they can't wait for what they were going to learn on that day. They were very interested."

The selection of appropriate materials determines whether the students can use L2 in speaking skills lessons. For instance, 8 teachers brought the pictures into the classroom as stimulus and this helped to encourage the students to use L2. The teachers demonstrated the ability to use the materials effectively in a specified context to engage and motivate the students. The students responded towards pictures as stimuli and this encouraged them to participate to share ideas and opinions. Therefore, the use of authentic materials is crucial in encouraging students to use L2 in real contexts.

\subsection{Teaching Techniques}

The observations also revealed that only three out of ten teachers carried out pre-communicative activities. In reality, such activities are necessary to be carried out by all L2 teachers to stimulate students' attention as well as to attract the students to participate.

From the observations, T1, T3, T4, T5, and T9 had carried out group work in the classroom during speaking skills lesson. The teachers believe that this technique is useful to be employed in the classroom. Four out of ten 
teachers applied this speaking activity in the classroom. T2, T6, T7, and T8 provided a few lines of dialogue for the students to be practised in pairs. Generally, it focuses on the grammar structure of the sentences where the students have to master such a typical technique in questioning and answering. T4 and T5 conducted role-play in teaching speaking skills. T9 said he carried out a drama for the first time. Not only the students were excited but the teacher was thrilled. According to T3 acting parts of the scenes from a novel made students active and vocal.

Brainstorming was another activity that T2 and T5 practised while teaching speaking skills. This activity required the students to produce ideas on a given topic or pictures. However, brainstorming had to be carried out in groups as they worked better as a group and had more confidence.

T5: "......and then, some kinds of brainstorming in groups because I believe that they were able to discuss in groups. They would gain more confidence and the ability to exchange ideas."

T4: "For my students, I like them to work in a group. They discuss and present it."

In this activity, students are required to describe pictures showed by the teachers. Below are the extracts related to the findings based on the activity conducted.

T7: "Normally, discussion or describing pictures and ask and answer questions worked.."

Using English songs in English language classrooms could successfully improve affective learning by providing a harmonious atmosphere in the classroom, reducing students' anxiety, fostering their interests and motivating them to learn the target language. Students will regard English songs as part of entertainment rather than work and thus find learning English through songs amusing and relaxed. Below are the extracts from the interview.

T4: "Yes, we sometimes do games when I look at them, they look very bored and tired. And yes, we sing songs..."

T5: $\quad$ 'So, maybe my next class they wanted to sing the songs from 'Tailor Swift', 'Katie Perrie' I had to get these CDs for the lesson."

T7: "Yes, of course, they like when we are watching videos, movies or singing activities, role play and also describing pictures. They love it very much."

When the teachers used games in class, students are provided with the opportunity to practise the speaking skills and to improve communication in L2.

T1: "Well, there are various. The first one would be scrabbling because I could see some of them enjoy scrabble."

Nine out of ten teachers focused on the students' fluency during the activities to improve their speaking skills. Meanwhile, correcting students' mistakes also played a crucial role in developing students' speaking skills. The teachers were aware of the problems faced by the students in speaking English. The students were afraid of making mistakes and did not have the confidence level to speak. Typical students' mistakes included the aspects of grammar, pronunciation, intonation, and vocabulary. Most L2 students mispronounced words according to spelling and because of this problem, they avoided speaking or giving out opinions during the classes. Nevertheless, most of the teachers believed that this is a minor problem as Malaysian students are ESL learners. Therefore, T1, T3, T4, T5, T7, and T9 chose to treat the mistakes later to avoid students from feeling threatened. They understood that they should not expect students to sound like native speakers. It would be good if the students were able to convey messages using English language clearly as agreed by the majority of the teachers.

\subsection{Challenges Faced by the Teachers}

The main challenge which cannot be denied in this study is the lack of proficiency of the students which leads to lack of confidence among them. This was a cyclical pattern as it led the teachers not only having difficulties in selecting appropriate speaking activities but to get students to participate. This was largely due to students having limited vocabulary to express ideas in L2 and shy away. Students who were afraid of making errors in pronunciation were found to be lacking in confidence in terms of speaking. It was seen that students were reluctant to participate in the activities although many of them understood the teachers' instructions. The finding is similar to Md Kawser Ahmed (2018).

Out of the 10 classrooms observations, eight observations proved that the students kept silent, were shy and passive when no questions were being prompted by the teachers. Therefore, low proficiency level and lack of confidence discouraged the students from taking part in most of the speaking activities conducted by the teachers in the classroom. The teachers needed to invite quiet students by prompting questions so that they would get involved in the discussions. Besides, lack of ICT skills and facilities was another challenge stated by the teachers. For instance, T5 felt that this problem hindered her to conduct effective communicative activities. Thus, it influenced the students' interest as they were eager and excited to learn when the teachers utilized computers and digital activities in the lesson.

Without using these facilities, students had less interest in the lessons. Even though they realized the importance of using it in the classroom, the teachers tried to utilize those facilities but they faced problems because the facilities provided are very limited as also found in a study by Mohd Zulhilmi \& Radzuwan (2019). T2, T4, 
and $\mathrm{T} 7$ said that the process of getting the equipment to be used was a problem. The equipment that they wanted to use was not always available for them since each school is provided with only one computer lab. Thus, they had to change their plan whenever they found other teachers were using it. Apart from that, the classroom setting in Malaysia with the physical setting of the tables and chairs as well as a large number of students in one class hindered the teachers in carrying out communicative activities such as group work and playing games.

Lack of conducive classroom arrangements affected their motivations level in their learning of L2. Besides that, the findings showed that each classroom observed had a large number of students in the class. Since the numbers of students were large, the teachers had difficulty to control the students in terms of using L1 especially when they talk to each other. This study had similar findings found in a study conducted by Muhammad Akbar, Habibullah Pathan, \& Syed Waqar Ali Shah (2018) regarding challenges faced by the teachers in terms of a large number of students, lack of related resources and interference of L1 in the classroom.

Moreover, other challenges faced by the teachers were regarding the time constraint and lack of support from the school. Husna Yahya, Abu Bakar Razali, \& Roselan Baki (2018) and Chin et al. (2017) also identified time constraint as one of the challenges faced by the teachers in teaching speaking skills effectively. The teachers just do not have the time, energy to prepare and continuous system support for these kinds of lessons, especially when it involves fixing LCDs or other electronic devices in the school (Mohd Zulhilmi \& Radzuwan 2019). They added that they had to do other administrative work which limited their time to prepare effective lessons to teach speaking skills.

Most of the teachers' responses claimed that they had created programmes such as 'Monday as the English day' and activities during the assembly to develop students' speaking skills. However, there was no support for their English program from the other teachers and administrators in the school. This problem could be due to the assumption that it was not important to learn speaking skills as it was not tested in exams. This finding was in line with Santibanez \& Gandara's (2018) study.

Essentially, teachers need to be enthusiastic about their teaching practices to promote the joy of learning L2 speaking skills in a classroom. To develop students' speaking skills, teaching practises should employ communicative activities, authentic materials, and students centred which students are given exposure to the CLT approach (Mohd Zulhilmi \& Radzuwan 2019). However, in implementing this approach into the classroom, the challenges faced by the teachers have to be catered first in our education system. Teachers' teaching practises influenced the students' learning habit or interest in learning. The students' learning habits are shaped by the materials and activities that they are exposed to. Therefore, the speaking activities and materials chosen should allow the students to speak and gain more experience in using it during the lessons. Thus, it definitely will help the students to master the language faster and be confident to use the language.

\section{Conclusion}

Although many teachers were found to employ various teaching practices and techniques based on CLT to develop students' speaking skills in the classroom, the problem remains significant among low proficient students. It could be hypothesized that one of the reasons for the students' incompetency in speaking skills is because our teachers still implemented the traditional method or teacher-centred rather than student-centred. Therefore, the teachers failed to develop students' speaking skills which became an issue to less competent students.

Instead of being the instructor which controls every interaction in the class, the teacher should be a facilitator to guide the students in learning and communication of L2 to provide more opportunities for students to interact by creating meaningful activities (Yukselturk, Altiok, \& Baser 2018). The findings of this study indicate that some of the teachers have promoted the communicative teaching practices in the teaching of speaking skills. However, many others were bound to the traditional approach that practices a teacher-centred approach. In terms of teaching materials, it was found that more teachers relied on the materials from the textbook given by the ministry rather than using authentic materials to assist them in the classroom. Some of them realized that they should present information through diverse media like realia, posters, and demonstrations to make English language input as comprehensible as possible. However, they employed the traditional method of teaching which chalk and talk rather than used teaching aids such as ICT tools to assist them in teaching speaking skills better. Teachers also used both L2 and L1 in conducting speaking skills lesson.

Teachers are seen as important agents of knowledge as well as agents of change, thus attention should be given to ensure that they employ effective teaching practices. However, the declining trend towards the implementation of the CLT approach in teaching and turn produced students who are not competent in speaking. The findings also describe the teaching practices that are still far away from the CLT approach and that students remain passive, shy, and only speak when they are asked by the teachers.

\section{REFERENCES}

Ashairi Suliman, Mohamed Yusoff Mohd Nor, \& Melor Md Yunus. (2018). Dual-Language Programme (DLP) Students' Level of Enthusiasm and Confidence: A Preliminary Study. Journal of Teaching \& Learning 
English in Multicultural Contexts, 2(1), 13-22.

Chin, D. Z., Lim, Y. C., Mok, J. Y., Saw, S. Q., \& Tey, L. Y. (2017). Study of In-Service Training, Job Promotion, Working Environment and Work Passion on Job Performance among the Primary Schools' English Teacher in Malaysia. Universiti Tunku Abdul Rahman, Faculty of Business and Finance, Department of Business. Selangor: http://eprints.utar.edu.my/2653/1/FYP G26.pdf.

Hazlina Aziz. (2016, September 28). New Straits Times. Retrieved June 3, 2019, from https://www.nst.com.my/news/2016/09/176566/raising-english-language-proficiency

Husna Yahya, Abu Bakar Razali, \& Roselan Baki. (2018). To Tell or Not to Tell: Exploring Malaysian Teachers' Perceptions towards Storytelling in English Classrooms. International Journal of Academic Research in Progressive Education and Development, 7(4), 319-339.

Jeyaraj, J. J., \& Harland, T. (2019). Linking Critical Pedagogy Practice to Higher Education in Malaysia: Insights from English Language Teachers. Asia Pacific Journal of Education, 39(1), 1-13.

June, T. L., \& Zanariah Pilus. (2019). International Students' Perspectives of Malaysian English Teachers' Spoken English. Indonesian Journal of Applied Linguistics, 8(3), 554-566. doi:10.17509/ijal.v8i3.15255

Kementerian Pendidikan Malaysia. (2003). Sukatan Pelajaran Kurikulum Bersepadu, Kurikulum Bersepadu Bahasa Inggeris Tingkatan Empat. Kuala Lumpur: Pusat Perkembangan Kurikulum.

Lim, I. K., Melor Md Yunus, \& Mohamed Amin Embi. (2017). Build Me Up: Overcoming Writing Problems among Pupils In A Rural Primary Schoo in Belaga, Sarawak, Malaysia. Jurnal Pendidikan Humaniora, 5(1), $1-7$.

Malaysia Education Blueprint 2015-2025 (Higher Education). (2016, January 17). Retrieved July 5, 2019, from Kementerian Pendidikan Malaysia: Pendidikan Tinggi: http://mohe.gov.my/muatturun/awam/penerbitan/pppm-2015-2025-pt/5-malaysia-education-blueprint-2015-2025-higher-education

McMurray, S., Dutton, M., McQuaid, R., \& Richard, A. (2016). Employer demands from business graduates. Education + Training, 58(1), 112-132.

Md Kawser Ahmed. (2018). Pedagogy in Speaking: Challenges Addressed by Teacher-Student in the ESL Context. International Journal of Applied Linguistics \& English Literature, 7(3), 97-107.

Moore, T., \& Morton, J. (2017). The myth of job readiness? Written communication, employability, and the 'skills gap' in higher education. Studies in Higher Education, 42(3), 591-609.

Muhammad Akbar, Habibullah Pathan, \& Syed Waqar Ali Shah. (2018). Problems Affecting L2 Learners' English Writing Skills: A Study of Public Sector Colleges Hyderabad City, Sindh, Pakistan. Language in India, 18, 7-26.

Pramela K., Kamisah Osman, Subahan T. and ZanatonIksan , 2014.Persepsi Pelajar Prasiswazah Program Pengajian Bahasa Inggeris Mengenai Kecekapan Kendiri dalam Kemahiran Kebolehgajian dalam Sektor Pekerjaan , Kajian Malaysia- Journal of Malaysian Studies 32 (2) , 93-112.

Rose, H., \& McKinley, J. (2018). Japan's English-medium Instruction Initiatives and the Globalization of Higher Education. Higher Education, 111-129.

Sakinah Nik Muhammad Naziman, \& Sharifah Raihan Syed Jaafar. (2018). The Adaptation Strategies of English Loanwords among Kelantan Malay Dialect Speakers. 3L: Language, Linguistics, Literature, 24(4), 128-142.

Siti Zaidah Zainuddin, Pillai, S., Dumanig, F. P., \& Phillip, A. (2019). English Language and Graduate Employability. Education + Training, 61(1), 79-93.

Talley, P., \& Tu, H.-l. (2014). Implicit and Explicit Teaching of English Speaking in the EFL Classroom. International Journal of Humanities and Social Science, 4(6), 38-45.

Tong, J. L., \& Ahmad, A. (2018). High School-University Disconnect: A Complex Issue in Malaysia. International Journal of Educational Management, 32(5), 851-865.

Yukselturk, E., Altiok, S., \& Baser, Z. (2018). Using Game-Based Learning with Kinect Technology in Foreign Language Education Course. Journal of Educational Technology \& Society, 21(3), 159-173. 